\title{
Laju Pertumbuhan dan Tingkat Kelangsungan Hidup Transplantasi Karang Acropora secale di Pantai Serangan dan Pantai Geger, Bali
}

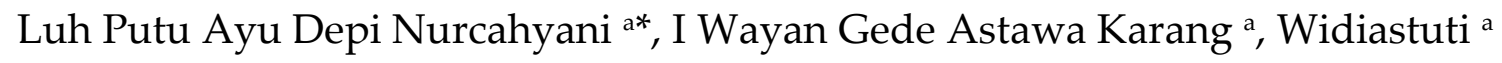 \\ aProgram Studi Ilmu Kelautan, Fakultas Kelautan dan Perikanan, Universitas Udayana, Kampus UNUD Bukit Jimbaran, Bali 80361, Indonesia \\ *Penulis koresponden. Tel.: +6285857407107 \\ Alamate-mail: depinurcahyani@gmail.com
}

Diterima (received) 16 Juli 2017; disetujui (accepted) 9 November 2017; tersedia secara online (available online) 10 November 2017

\begin{abstract}
The status of Indonesian coral reefs are in fair to poor categories, therefore it requires more approaches in order to recover the natural ecosystem. One of the reef restoration method is coral transplantation. Genus Acropora is one of the main constituent of reefs in the Indo-Pacific waters. Reef transplantation may not only rehabilitate the damaged reef, but also an effective way to collect coral for economic purposes. Acropora secale has high economic value as aquarium ornament, however it is vulnerable to the environmental stress and marine pollution. Therefore, finding the suitable transplantation location is one of important part in the transplantation. The objective of this research is to investigate the growth of transplant A. Secale at Serangan and Geger Beach which has different morphology feature. A. secale was Transplanted for 3 months on the $2 \times 1 \mathrm{~m}$ table with 16 fragments and observed each week. The results obtained are total growth and growth rate of $A$. secale transplanted on Serangan Beach is significant higher than Geger Beach $(\mathrm{P}<0.05)$. The total growth of $A$. secale on Serangan Beach is higher by $0,83 \mathrm{~cm}$, wider by $0,61 \mathrm{~cm}$, and branches are more 7 branches than Geger Beach. The growth rate of $A$. secale at Serangan Beach was higher by 0,27 cm/month and wider by $0,21 \mathrm{~cm} / \mathrm{month}$ than Geger Beach. The survival rate of $A$. secale on Serangan Beach and Geger Beach is $100 \%$ which means that all transplanted corals survive until the end of the study.
\end{abstract}

Keywords: coral transplantation A. secale; growth; Serangan Beach; GegerBeach

\begin{abstract}
Abstrak
Status terumbu karang di Indonesia didominasi oleh terumbu karang kondisi cukup hingga kurang baik, sehingga diperlukan upaya untuk memperbaiki ekosistem alami. Salah satu metode perbaikan terumbu karang adalah dengan transplantasi. Genus Acropora merupakan jenis penyusun utama pada terumbu di perairan Indo-Pasifik. Transplantasi karang tidak hanya merehabilitasi karang yang rusak, tapi juga merupakan metode yang efektif untuk memanfaatkan karang untuk tujuan ekonomis. A. secale memiliki nilai ekonomi yang tinggi sebagai hiasan akuarium, namun rentan terhadap tekanan lingkungan dan polusi laut. Mengetahui lokasi transplantasi yang paling sesuai merupakan salah satu hal yang penting dalam transplantasi. Penelitian ini bertujuan untuk mengetahui pertumbuhan A. secale yang di transplantasikan di Pantai Serangan dan Pantai Geger yang memiliki perbedaan morfologi. A. secale ditransplantasikan selama 3 bulan pada meja berukuran $2 \times 1 \mathrm{~m}$ dengan 16 fragmen dan diamati setiap minggu. Hasil yang didapatkan yaitu pertumbuhan total dan laju pertumbuhan A. secale yang ditransplantasikan di Pantai Serangan lebih tinggi secara signifikan daripada Pantai Geger. Pertumbuhan total A. secale di Pantai Serangan lebih tinggi sebesar 0,83 cm, lebih lebar sebesar 0,61 cm, dan cabang lebih banyak 7 cabang dibandingkan Pantai Geger. Laju Pertumbuhan $A$. secale di Pantai Serangan lebih tinggi sebesar 0,27 cm/bulan dan lebih lebar sebesar 0,21 cm/bulan dibandingkan Pantai Geger. Tingkat kelangsungan hidup A. secale yang ditransplantasikan di Pantai Serangan dan Pantai Geger adalah $100 \%$ yang berarti semua karang yang ditransplantasikan bertahan hidup hingga akhir penelitian.
\end{abstract}

Kata Kunci: transplantasi karang; A. secale; pertumbuhan; Pantai Serangan; Pantai Geger 


\section{Pendahuluan}

Degradasi ekosistem terumbu karang yang terjadi secara global akibat perubahan iklim, eutrofikasi, penangkapan berlebih dan pencemaran telah menjadi perhatian dunia (Hughes and Connell, 1999). Sebagian besar penyebab degradasi tersebut adalah aktifitas manusia seperti aktivitas perikanan yang merusak dan wisata bahari yang tidak terkontrol (Taofiqurohman, 2013; Uar, 2016). Kondisi terumbu karang di Indonesia umumnya didominasi oleh kategori cukup $(37,42 \%)$ hingga kurang baik (30,07\%) (COREMAP, 2014). Hal ini disebabkan oleh penangkapan ikan dengan menggunakan kalium sianida ( $\mathrm{KCN})$ atau peledak, kegiatan wisata bawah air yang tidak ramah lingkungan, serta aktifitas tangkap lebih (overfishing) terhadap ikan pemakan alga (Vatria, 2010; Pontoh, 2011; Manullang et al., 2014). Selain itu, pengambilan terumbu secara ilegal untuk dijadikan pondasi rumah, ornamen akuarium dan pembuatan jalan juga berkontribusi terhadap kerusakan ekosistem ini (Santoso, 2010; Sembiring et al., 2012). Oleh karena itu, diperlukan upaya untuk merehabilitasi degradasi tersebut dan mencegah pengambilan terumbu di alam, salah satunya adalah metode transplantasi. Transplantasi karang adalah metode untuk memulihkan terumbu yang terdegradasi dengan teknik pencangkokan.

Pertumbuhan karang dipengaruhi oleh faktor lingkungan seperti kecerahan, arus, kedalaman, suhu, salinitas, dan pH (Dodge and Vaisnys, 1975). Faktor-faktor lingkungan tersebut dapat bervariasi antar lokasi transplantasi. Dalam rangka mendapatkan laju pertumbuhan dan tingkat kelangsungan hidup karang transplan yang optimum, maka transplantasi karang $A$. secale dilakukan pada 2 pantai yaitu Pantai Serangan dan Geger. Pantai Serangan merupakan kawasan konservasi di wilayah pesisir Kota Denpasar (Peraturan Presiden No 45 Tahun 2011) sedangkan Pantai Geger merupakan kawasan wisata alam Kabupaten Badung (Perda Kab Badung No 26 Tahun 2013). Selain itu lokasi di Pantai Serangan juga lebih terlindung dibandingkan Pantai Geger sehingga arus di Pantai Geger lebih kuat daripada Pantai Serangan. Hal ini dapat menjadi salah satu faktor yang mempengaruhi pertumbuhan karang di kedua pantai.

Karang Genus Acropora merupakan jenis penyusun utama pada terumbu di perairan IndoPasifik (Aeby et al.,, 2011). Selain pemanasan global, karang jenis ini juga mengalami ancaman degradasi akibat perdagangan karang hias ilegal. A. Secale merupakan salah satu komoditas ekspor bernilai ekonomis tinggi dan telah memiliki izin untuk diperdagangkan (DITJEN PHKA, 2012). Budidaya karang jenis ini dengan cara transplantasi dapat mengurangi dan merehabilitasi kerusakan terumbu serta menambah pendapatan ekonomi nelayan pembudidaya.

\section{Metode Penelitian}

\subsection{Waktu dan Tempat}

Penelitian dilaksanakan selama 3 bulan, yaitu Januari 2016 - Maret 2017. Pengamatan pertumbuhan dan pengukuran parameter lingkungan dilakukan setiap minggu, dimana aspek pertumbuhan yang diamati adalah jumlah cabang dan ukuran fragmen karang (tinggi dan lebar). Transplantasi di Pantai Serangan berlokasi di lokasi budidaya karang CV. Cahaya Baru, Kota Denpasar. Sedangkan, transplantasi di Pantai Geger berlokasi di kawasan wisata Pantai Geger, Kabupaten Badung (Gambar 1).

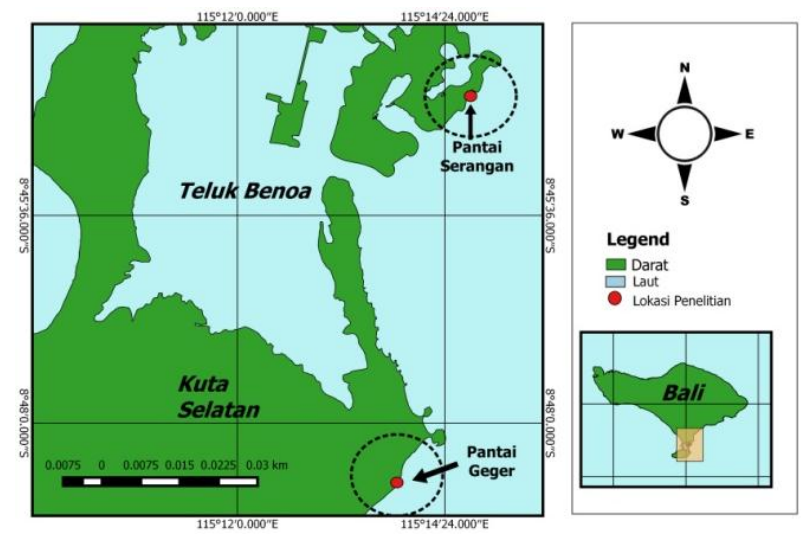

Gambar 1. Peta Lokasi Penelitian

\subsection{Konstruksi Meja Transplantasi}

Meja untuk tempat transplantasi terbuat dari besi berbentuk persegi panjang dengan ukuran $2 \times 1 \mathrm{~m}$ dengan tinggi 0,5 m (Gambar 2). Pada meja tersebut di letakkan rak sebagai tempat untuk meletakkan substrat semen.

\subsection{Pemotongan Karang Induk dan Penempatan Meja Transplantasi}

Indukan karang $A$. secale yang dipakai merupakan hasil budidaya oleh CV Cahaya Baru di Pantai 
Serangan. Pemotongan karang induk dilakukan dengan memotong cabang pada karang induk menggunakan pemotong karang (Gambar 3). Fragmen karang yang ditransplantasikan berjumlah 32 fragmen. Fragmen karang selanjutnya diikatkan pada substrat semen dan disusun pada meja transplantasi.

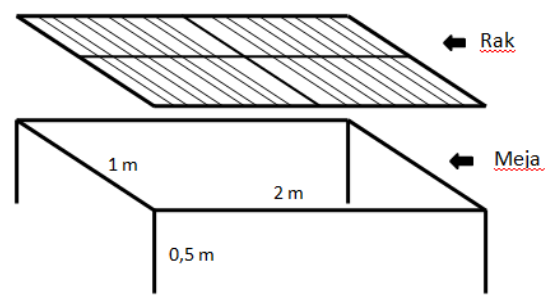

Gambar 2. Konstruksi Meja Transplantasi
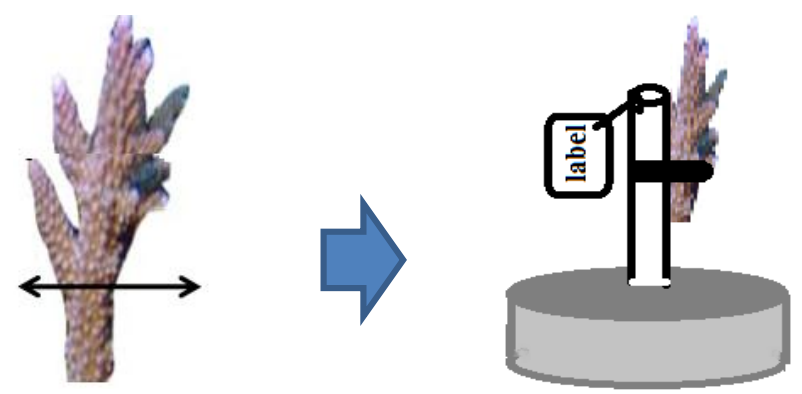

Gambar 3. Ilustrasi cara pemotongan fragmen karang dan pengikatan pada substrat semen

Meja transplantasi diletakkan di perairan Pantai Serangan dan Pantai Geger pada kedalaman $\pm 1 \mathrm{~m}$. Setiap meja transplantasi diisi dengan 16 fragmen karang.

\subsection{Pengamatan Pertumbuhan}

Pengukuran pertumbuhan karang menggunakan jangka sorong yang didasarkan atas pertumbuhan tinggi, lebar, dan percabangan karang. Hasil pengamatan kemudian dicatat pada kertas yang telah disiapkan.

\subsection{Analisis Data}

Pertumbuhan total karang yang ditransplantasikan dihitung menggunakan persamaan (1).

$\beta=L_{t}-L_{0}$

Dimana $\beta$ adalah pertumbuhan panjang/ tinggi/ cabang fragmen karang, Lt adalah rata-rata panjang/ tinggi/ jumlah cabang fragmen karang pada akhir penelitian, Lo adalah Rata-rata panjang/ tinggi/ jumlah cabang fragmen karang pada awal penelitian.

Laju pertumbuhan transplatasi karang dihitung dengan menggunakan persamaan (2).

$\alpha=\frac{L_{i+1}-L_{i}}{t_{i+1}-t_{i}}$

dimana A adalah laju pertumbuhan panjang atau lebar fragmen karang, $L_{i+1}$ adalah tinggi atau lebar fragmen pada waktu ke i+1, $L_{i}$ adalah tinggi atau lebar fragmen pada waktu ke i, $t_{i+1}$ adalah waktu ke $\mathrm{i}+1$, dan $t_{i}$ adalah waktu ke $\mathrm{i}$

Tingkat kelangsungan hidup pada karang yang ditransplantasi dihitung dengan menggunakan persamaan (3).

$S R=\frac{\mathrm{Nt}}{\mathrm{No}} \times 100 \%$

dimana SR adalah tingkat Kelangsungan Hidup (Survival Rate), Nt adalah jumlah fragmen karang pada akhir penelitian, dan No adalah jumlah fragmen karang pada awal penelitian

Perbedaan pertumbuhan total dan laju pertumbuhan antara dua pantai yang berbeda dianalisa dengan Uji T dengan software Microsoft Excel 2007.

\section{Hasil dan Pembahasan}

\subsection{Kondisi Lingkungan}

Kondisi lingkungan kedua lokasi transplantasi ditunjukkan pada Tabel 1. Rata-rata suhu di Pantai Serangan yaitu $29,46^{\circ} \mathrm{C}$ dan di Pantai Geger 29,73으, suhu di kedua pantai tidak berbeda jauh. Kedalaman di Pantai Serangan dan Pantai Geger sama-sama $1 \mathrm{~m}$. Rata-rata kecepatan arus di Pantai Serangan 0,10 m/s dan di Pantai Geger 0,11 m/s. Nilai kecerahan yang didapatkan pada kedua lokasi penelitian yaitu $100 \%$. Rata-rata salinitas di Pantai Serangan 32,42 ppt dan di Pantai Geger 32,58 ppt. Selanjutnya rata-rata nilai $\mathrm{pH}$ di Pantai Serangan 8,19 dan di Pantai Geger 8,08. Nilai dari semua parameter lingkungan yang diukur di Pantai Serangan dan Pantai Geger menunjukan nilai yang hampir sama.

\subsection{Pertumbuhan Karang A. secale}

Hasil pengukuran pertambahan tinggi, lebar, dan percabangan karang tranplan di kedua pantai 
menunjukan pertambahan setiap minggu (Gambar 4). Pada akhir pengamatan pertumbuhan tinggi total karang transplan di Pantai Serangan secara signifikan lebih tinggi yaitu sebesar 1,51 $\pm 0,31 \mathrm{~cm}$ daripada pertumbuhan tinggi total di Pantai Geger yaitu $0,68 \pm 0,20 \mathrm{~cm}$ (Gambar 5). Pertumbuhan lebar total karang transplan di Pantai Serangan juga secara signifikan lebih besar yaitu sebesar 1,28 $\pm 0,34 \mathrm{~cm}$ dibandingkan di Pantai Geger yaitu 0,67 $\pm 0,23 \mathrm{~cm}(\mathrm{P}<0,05)$. Hal yang sama juga terlihat pada pertambahan cabang total yang secara signifikan lebih banyak 7 cabang di Pantai Serangan daripada di Pantai Geger $(\mathrm{P}<$ 0,05) (Gambar 6).

\section{Tabel 1}

Parameter Lingkungan di Pantai Serangan dan Pantai Geger

\begin{tabular}{lcc}
\hline \multicolumn{1}{r}{ Parameter } & Serangan & Geger \\
\hline Suhu $\left({ }^{\circ} \mathrm{C}\right)$ & 29.46 & 29.73 \\
Kedalaman $(\mathrm{m})$ & 1 & 1 \\
Kec. Arus $(\mathrm{m} / \mathrm{s})$ & 0.10 & 0.11 \\
Kecerahan $(\%)$ & $100 \%$ & $100 \%$ \\
Salinitas $(\mathrm{ppt})$ & 32.42 & 32.58 \\
$\mathrm{pH}$ & 8.19 & 8.08 \\
\hline
\end{tabular}

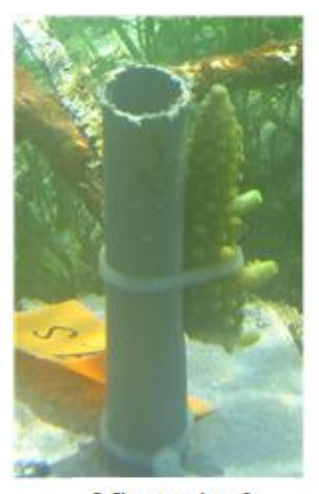

Minggu ke- 0
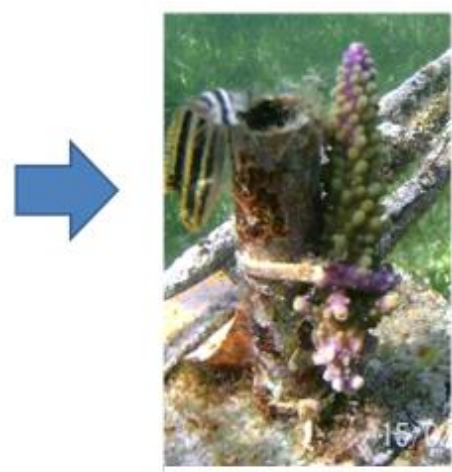

Minggu ke-12
Gambar 4. Pertumbuhan setelah 12 minggu

Perbedaan signifikan pada pertumbuhan total tinggi, lebar, dan cabang A. secale antara Pantai Serangan dan Pantai Geger dimungkinkan karena limbah dari aktifitas manusia di darat yang terbawa ke laut akan menyebabkan peningkatan bahan organik dan mempercepat pertumbuhan makroalga (Djaelani et al., 2011; Oktafiani dan Hermana, 2013; Kepel et al., 2015). Berdasarkan observasi penulis, makroalga tumbuh dengan cepat pada lokasi transplantasi di Pantai Geger dibandingkan dengan di Pantai serangan. Alga yang hidup menempel pada karang dapat mengganggu pertumbuhan, produktivitas, dan kelangsungan hidup karang karena dapat menghalangi cahaya yang dibutuhkan zooxanthella pada karang untuk proses fotosintesis (Bukepile and Hay, 2010; D'Angelo and Wiedenmann, 2014). Zooxanthella memiliki peran penting dalam proses kalsifikasi karang (proses pembentukan kerangka kapur) (Pearse and Muscatine, 1971; Al-Hammady, 2013).

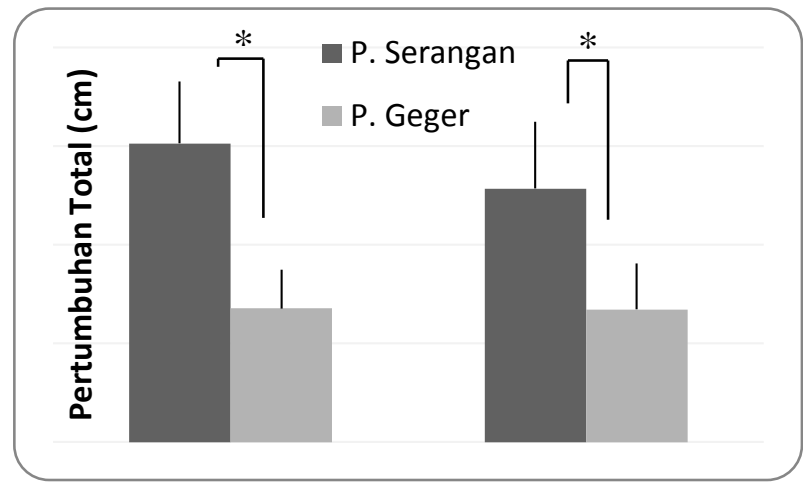

Gambar 5. Pertumbuhan Tinggi dan Lebar Total $A$. secale di Pantai Serangan dan Pantai Geger. Tanda “*” menunjukan perbedaan signifikan

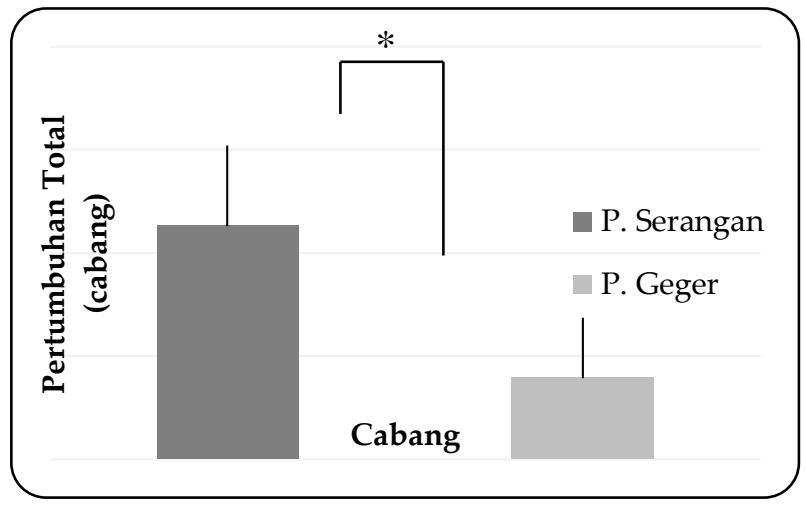

Gambar 6. Pertambahan Cabang Total A. secale di Pantai Serangan dan Pantai Geger. Tanda “*” menunjukan perbedaan signifikan

Selain itu terdapat biota penganggu yaitu bulu babi yang dijumpai sepanjang penelitian. Pada awal penelitian dijumpai banyak bulu babi pada lokasi transplantasi di Pantai Geger (Gambar 7), namun setelah bulan kedua bulu babi mulai berkurang hingga pada akhir transplantasi hanya terlihat empat bulu babi di sekitar meja transplantasi. Adanya bulu babi dapat mengganggu pertumbuhan dari karang yang ditransplantasikan. Korzen et al. (2011) menyatakan saat memakan alga pada karang, bulu babi dapat mengikis kalsium dari terumbu 
karang tersebut, bahkan bulu babi juga ditemukan dapat memakan karang yang masih hidup.

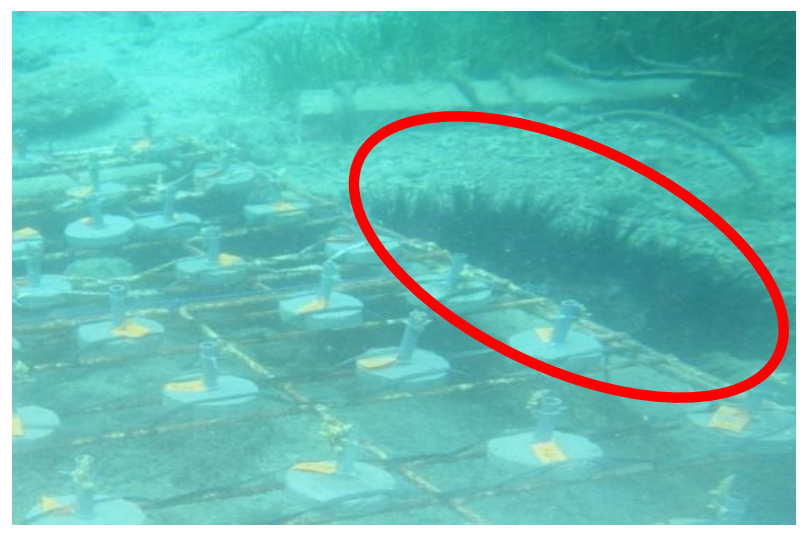

Gambar 7. Bulu babi pada lokasi transplantasi Pantai Geger. Lingkaran merah menunjukkan bulu babi.

Karang yang ditransplantasikan berasal dari Pantai Serangan sehingga dapat mempermudah karang dalam proses adaptasi dan tidak menimbulkan banyak tekanan pada karang. Sedangkan karang akan lebih sulit beradaptasi pada lokasi transplantasi Pantai Geger karena bibit karang tidak berasal dari pantai ini. Karang yang ditransplantasikan di Pantai Geger mengalami stress pada awal penelitian yang ditandai dengan keluarnya lendir pada permukaan karang. Hal ini membuktikan bahwa karang sedang beradaptasi dengan lingkungan yang baru.

\subsection{Laju Pertumbuhan Karang A. secale}

Laju pertumbuhan tinggi dan lebar karang transplan di Pantai Serangan lebih tinggi secara signifikan daripada di Pantai Geger $(p<0.05)$ (Gambar 8). Laju pertumbuhan tinggi di Pantai Serangan yaitu sebesar $0,5 \pm 0,10 \mathrm{~cm} /$ bulan dan di Pantai Geger yaitu sebesar 0,23 $\pm 0,07 \mathrm{~cm} /$ bulan. Sedangkan, laju pertumbuhan lebar karang transplan di Pantai Serangan yaitu sebesar 0,43 \pm $0,11 \mathrm{~cm} /$ bulan dan di Pantai Geger yaitu sebesar $0,22 \pm 0,08 \mathrm{~cm} / \mathrm{bulan}$.

Nilai laju pertumbuhan tinggi dan lebar $A$. secale yang ditransplantasikan di Pantai Serangan menunjukkan perbedaan yang signifikan bila dibandingkan dengan laju pertumbuhan $A$. secale yang ditransplantasikan di Pantai Geger $(P<0,05)$. Laju pertumbuhan A. secale di Pantai Geger lebih rendah daripada di Pantai Serangan. Hal ini menunjukkan bahwa perbedaan lokasi transplantasi mempengaruhi laju pertumbuhan $A$. secale karena setiap lokasi transplantasi memiliki kondisi lingkungan yang berbeda. Pada Pantai Geger terdapat biota yang dapat mengganggu pertumbuha karang seperti adanya makroalga dan bulu babi.

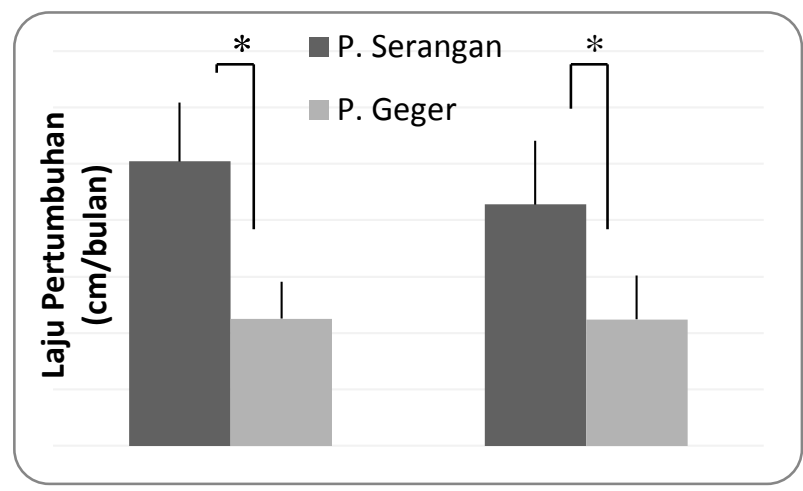

Gambar 8. Laju Pertumbuhan Tinggi dan Lebar A. secale di Pantai Serangan dan Pantai Geger. Tanda “*” menunjukan perbedaan signifikan.

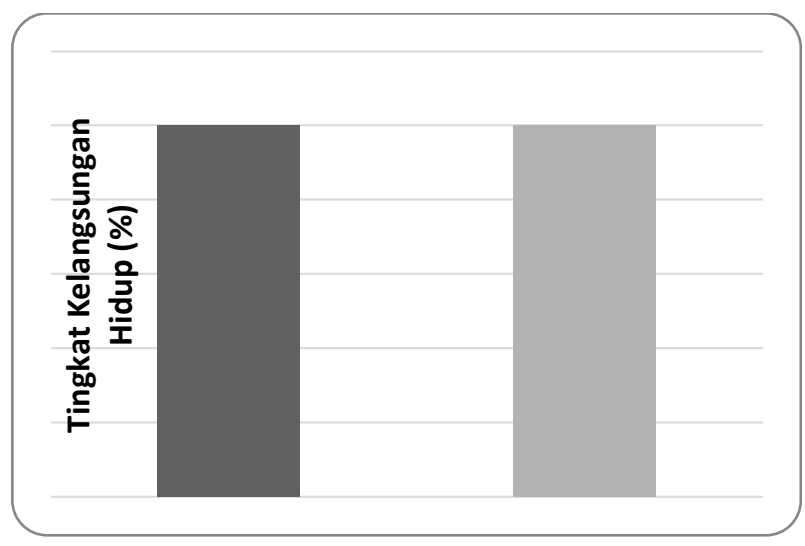

Gambar 9. Tingkat Kelangsungan Hidup A. secale di Pantai Serangan dan Pantai Geger

\subsection{Tingkat Kelangsungan Hidup A. secale}

Tingkat kelangsungan hidup A. secale pada kedua lokasi transplantasi menunjukkan hasil yang sama yaitu sebesar 100\% hidup (Gambar 9). Tingkat kelangsungan hidup yang tinggi menunjukan bahwa karang $A$. secale memiliki ketahanan hidup yang tinggi, seperti yang jumpai pada lokasi transplan perairan Teluk Awur, Jepara dengan membandingkan ukuran awal fragmen $A$. aspera, yaitu $3 \mathrm{~cm}, 5 \mathrm{~cm}$, dan $7 \mathrm{~cm}$. Pada penelitian tersebut didapatkan tingkat kelangsungan hidup $100 \%$ pada ukuran awal $5 \mathrm{~cm}$ dan $7 \mathrm{~cm}$, sedangkan 87,5\% pada ukuran awal $3 \mathrm{~cm}$ (Yunus, 2013). Penelitian oleh Hermanto (2015) menunjukan tingkat kelangsungan hidup $A$. formosa yang ditransplantasikan di perairan Selat Lembeh, Sulawesi Utara mencapai $85 \%$, nilai ini lebih 
rendah daripada hasil yang didapatkan pada penelitian ini.

\section{Simpulan}

Dari hasil dan pembahasan diatas dapat ditarik kesimpulan bahwa pertumbuhan total $A$. secale yang ditransplantasikan di Pantai Serangan secara signifikan lebih tinggi daripada Pantai Geger. Pertumbuhan total di Pantai Serangan yaitu tinggi $15,12 \pm 3,13 \mathrm{~mm}$, lebar 12,83 $\pm 3,39 \mathrm{~mm}$, dan cabang $11,31 \pm 3,88$ cabang, sedangakan di Pantai Geger yaitu tinggi $6,77 \pm 1,96 \mathrm{~mm}$, lebar $6,72 \pm 2,32 \mathrm{~mm}$, dan cabang 3,94 $\pm 2,91$ cabang.

Laju Pertumbuhan $A$. secale yang ditransplantasikan di Pantai Serangan secara signifikan lebih tinggi daripada Pantai Geger. Laju pertumbuhan di Pantai Serangan yaitu tinggi 5,04 $\pm 1,04 \mathrm{~mm} /$ bulan, lebar 4,28 $\pm 1,13 \mathrm{~mm} /$ bulan, dan cabang 3,77 $\pm 1,29$ cabang/bulan, sedangakan di Pantai Geger yaitu tinggi 2,26 \pm 0,65 mm/bulan, lebar 2,24 \pm 0,77 mm/bulan, dan cabang 1,31 $\pm 0,97$ cabang/bulan.

Tingkat kelangsungan hidup $A$. secale yang ditransplantasikan di Pantai Serangan sama dengan Pantai Geger yaitu 100\% yang berarti semua karang yang ditransplantasikan bertahan hidup hingga akhir penelitian.

\section{Ucapan Terimakasih}

Penulis mengucapkan terima kasih kepada CV. Cahaya Baru yang telah memberikan bantuan berupa alat dan bahan sehingga dalam pelaksanaannya penelitian ini dapat berjalan dengan lancar. Ucapan terimakasih juga penulis sampaikan kepada Ibu Elok Faiqoh, S.Pi., M.Si, Bapak Ir. I Gusti Ngurah Putra Dirgayusa, MT, dan Bapak Prof. Ir. IGB Sila Dharma, MT., Ph.D atas kritik dan saran yang diberikan.

\section{Daftar Pustaka}

Aeby, G. S., Williams, G. J., Franklin, E. C., Haapkyla, J., Harvell, C. D., Neale, S., Page, C. A., Raymundo, L., Vargas-Angel, B., Willis, B. L., Work, T. M., \& Davy, S. K. (2011). Growth anomalies on the coral genera Acropora and Porites are strongly associated with host density and human population size across the Indo-Pacific. PloS one, 6(2), e16887.

Al-Hammady, M. A. M. (2013). The Effect of Zooxanthellae Availability on the Rates of Skeletal Growth in the Red Sea Coral Acropora Hemprichii. Egyptian Journal of Aquatic Research, 39(1), 177-183.
Burkepile, D. E., \& Hay, M. E. (2010). Impact of Herbivore Identity on Algal Succession and Coral Growth on a Caribbean Reef. PLOS ONE, 5(1), 1-9.

COREMAP (2014). Kondisi Terumbu Karang di Indonesia. [online] Tersedia di: http://www.coremap.or.id/Kondisi-TK/?yr=2014, [diakses: 25 Oktober 2016].

D'Angelo, C., \& Wiedenmann, J. (2014). Impacts of Nutrient Enrichment on Coral Reefs: New Perspectives and Implications for Coastal Management and Reef Survival. Current Opinion in Environmental Sustainability, 7(1), 82-93.

DITJEN PHKA. (2012). Buku Informasi Jenis-Jenis Karang Hias Hasil Transplantasi. Jakarta, Indonesia: Direktorat Jendral Perlindungan Hutan dan Konservasi Alam.

Djaelani, A., Damar, A., \& Rahardjo, S. (2011). Kajian Kondisi Terumbu Karang dan Kaitannya dengan Proses Eutrofikasi di Kepulauan Seribu. Jurnal IlmuIlmu Perairan dan Perikanan Indonesia, 17(1), 187-194.

Dodge, R. E., \& Vaisnys, J. R. (1975). Hermatypic Coral Growth Banding as Environmental Recorder. Nature, 258(5537), 706-708.

Hermanto, B. (2015). Pertumbuhan Fragmen Acropora formosa pada Ukuran yang Berbeda dengan Metode Transplantasi di Perairan Selat Lembeh. Jurnal Ilmiah Platax, 3(2), 90-100.

Hughes, T. P., \& Connell, J. H. (1999). Multiple stressors on coral reefs: A long-term perspective. Limnology and oceanography, 44(3part2), 932-940.

Kepel, R. C., Mantiri, D. M. H., \& Manu, G. D. (2015). Pertumbuhan Alga Cokelat Padina australis Hauch di Perairan Pesisir, Desa Kampung Ambon, Kecamatan Likupang Timur, Kabupaten Minahasa Utara. Jurnal LPPM Bidang Sains dan Teknologi, 2(2), 78-85.

Korzen, L., Israel, A., \& Abelson, A. (2011). Grazing Effects of Fish versus Sea Urchins on Turf Algae and Coral Recruits: Possible Implications for Coral Reef Resilience and Restoration. Journal of Marine Biology, 2011, 960207.

Manullang, J. C., Hartoni, H., \& Surbakti, H. (2014). Analisis Perubahan Luasan Terumbu Karang dengan Menggunakan Data Penginderaan Jauh di Perairan Pulau Pramuka Kabupaten Administratif Kepulauan Seribu. Maspari Journal, 6(2), 124-132.

Oktafiani, M., \& Hermana, J. (2013). Pengaruh Konsentrasi Nutrien dan Konsentrasi Bakteri Pada Produksi Alga Dalam Sistem Bioreaktor Proses Batch. Jurnal Teknik ITS, 2(2), D57-D62.

Pearse, V. B., \& Muscatine, L. (1971). Role Of Symbiotic Algae (Zooxanthellae) In Coral Calcification. The Biological Bulletin, 141(2), 350-363.

Pemkab Badung. (2013). Peraturan Daerah Kabupaten Badung No 26 Tahun 2013 tentang Rencana Tata Ruang Wilayah Kabupaten Badung Tahun 2013-2033. Lembaran Daerah Kabupaten Badung Tahun 2013 Nomor 26. Badung, Indonesia: Pemerintah Daerah Kabupaten Badung. 
Republik Indonesia. (2011). Peraturan Presiden No 45 Tahun 2011 Tentang Rencana Tata Ruang Kawasan Perkotaan Denpasar, Badung, Gianyar, dan Tabanan. Lembaran Negara Republik Indonesia Nomor 121 Tahun 2014. Jakarta, Indonesia: Sekretariat Kabinet Republik Indonesia.

Pontoh, O. (2011). Penangkapan Ikan dengan Bom di Daerah Terumbu Karang Desa Arakan dan Wawontulap. Jurnal Perikanan dan Kelautan Tropis, $7(1), 56-59$.

Santoso, A. D. (2010). Kondisi Terumbu Karang di Pulau Karang Congkak Kepulauan Seribu. Jurnal Hidrosfir Indonesia, 5(2), 73-78.

Sembiring, I., Wantasen, A. S., \& Ngangi, E. L. A. (2012). Kajian Sosial Ekonomi Masyarakat dalam Pemanfaatan Terumbu Karang di Desa Tumbak Kabupaten Minahasa Tenggara. Jurnal Ilmiahh Platax, 1(1), 29-36.

Sembiring, I., Wantasen, A. S., \& Ngangi, E. L. A. (2012). Manfaat Langsung Terumbu Karang di Desa Tumbak
Kabupaten Minahasa Tenggara. Jurnal Perikanan dan Kelautan Tropis, 8(2), 58-63.

Taofiqurohman, A. (2013). Penilaian tingkat risiko terumbu karang akibat dampak aktivitas penangkapan ikan dan wisata bahari di Pulau Biawak, Jawa Barat. DEPIK Jurnal Ilmu-Ilmu Perairan, Pesisir dan Perikanan, 2(2), 50-57.

Uar, N. D., Murti, S. H., \& Hadisusanto, S. (2016). Kerusakan Lingkungan Akibat Aktivitas Manusia pada Ekosistem Terumbu Karang. Majalah Geografi Indonesia, 30(1), 88-96.

Vatria, B. (2010). Berbagai Kegiatan Manusia yang dapat Menyebabkan Terjadinya Degradasi Ekosistem Pantai serta Dampak yang Ditimbulkannya. Jurnal Belian, 9(1), 47-54.

Yunus, B. H., Wijayanti, D. P., \& Sabdono, A. (2013). Transplantasi Karang Acropora aspera dengan Metode Tali di Perairan Teluk Awur, Jepara. Buletin Oseanografi Marina, 2(3), 22-28.

(C) 2017 by the authors; licensee Udayana University, Indonesia. This article is an open access article distributed under the terms and conditions of the Creative Commons Attribution license (http://creativecommons.org/licenses/by/3.0/). 